\title{
Wool characteristics of crossbred Baghdadi wild ram and Iran native sheep
}

\author{
Nosratollah Taherpour, Farhad Mirzaei ${ }^{*}$ \\ Animal Science Research Institute of Iran, Karaj, Iran; *Corresponding Author: farmir2003203@yahoo.com
}

Received 20 December 2011; revised 27 January 2012; accepted 1 February 2012

\section{ABSTRACT}

Twenty mid side wool samples of crossbred sheep were collected and their characteristics were determined. Data analyzed by SAS software and Duncan's multiple range tests was used for comparison of mean wool characteristics. Average fleece weight, yield, wool diameter, Fine fiber and staple length were: $431.59 \pm 38.95 \mathrm{gr}, 65.14 \%$, $14.24 \pm 0.67 \mu \mathrm{m}, 48.67 \pm 5.59$, and $43.65 \pm 4.15$ $\mathrm{mm}$ respectively. Mean fleece weight was significantly affected $(p<0.05)$ by sex (female 259 gr and male 506.55) and age $(248.25,458.38$ and $637.75 \mathrm{gr}$ for 1,2 and 3 yr old respectively). Mean wool diameter was significantly affected by sex (male $12.78 \pm 0.49$, female $15.33 \pm 0.85 \mu \mathrm{m}$ ) and there was a significant difference $(p<0.05)$ between $F_{1}$ and $F_{2}$ generation $11.84 \pm 0.58,16.27 \pm$ $0.72 \mu \mathrm{m}$ respectively. There were effective differences among ages $(12.55 \pm 0.74,14.47 \pm 0.58$ and $13.11 \pm 0.64 \mu \mathrm{m}$ for 1,2 and 3 yr old respectively). Wool diameter of younger animals, males and $F_{1}$ was so fine $(12.55,12.87$ and $11.84 \mu \mathrm{m}$ respectively). Staple length of $F_{2}$ crosses was significantly longer than $F_{1}$ crosses $(p<0.05)$. However wool diameter of $F_{1}$ was significantly finer than $F_{2}$, but length and down fiber percentage was less than second generation. As wild sheep shed his fiber in winter, the first filial crosses also shed their fibers from the end of winter to early spring. Shedding was seldom observed in $F_{2}$ generations. It seems likely that wool from crossbred sheep could be used for those applications for which cashmere is suitable. This study indicates that, such crossbred sheep have a superfine wool and could be used in pure or blend for textile industry.

Keywords: Wool Characteristics; Farahani Sheep; Crossbreeding; Superfine Wool; Wild Sheep; Carpet Wool

\section{INTRODUCTION}

Meat production is the first priority of sheep breeding in Iran and wool production is second or third purpose. The sheep population in Iran is about 53 million heads (14 breeds); their wool is used for hand made carpet. About $60 \%$ of wool color of these sheep is white - cream and mean wool diameter is $30-38 \mu \mathrm{m}$ [1]. All of worsted factories needs fine wool and some of raw wool for hand made woven carpet imported from abroad.

Farahani is one of the Iran native carpet wool type sheep breed, horned and white wool that is raised in central part of Iran and its wool characteristics: wool yield $65 \%$, fiber length $110 \mathrm{~mm}$, wool diameter $25-27 \mu \mathrm{m}$ crimp $/ 10 \mathrm{~cm} 25$ [2]. Wool yield $66.2 \%-82.9 \%$, fiber length $10-11.8 \mathrm{~cm}$, wool diameter $25.6-31 \mu \mathrm{m}$ [3]. There are 3 types of wild sheep in Iran, that Baghdadi type is living in Haft Gholle Mountain in central part of Iran. Their population is about 2000 heads (local office for statistic, 1997). Rams are horned and females are polled, their coats are kempy and brown and black color at the tip fiber [4]. Aliev and Racgkorskii [5] reported the diameter of inner coat of wild sheep is $7-20 \mu \mathrm{m}$ and outer coat $100-200 \mu$ with brown color. Pakov [6] reported, fiber diameter of wild sheep is $12.06-14.40 \mu \mathrm{m}$.

The main aim of this research is attributed to the effect of age, sex and generation on quality and quantity of wool characteristics crossbred sheep and its uses in textile industry.

\section{MATERIALS AND METHODS}

The semen of wild ram (Baghdadi) collected by electrical ejaculation and fertilization of Farahani ewes carried out by artificial insemination.

The data pertained to the crossbreeding experiment for improving the wool production and quality involving Baghdadi wild ram and Farahani native sheep. Twenty right mid side wool samples of crossbred sheep were collected at the end of winter and their characteristics were determined. Staple length measured with ruler before shearing and sampling. Fleece weight determined by digital balance. Yield of wool obtained by washing with 
none ionic detergent in 4 scouring bowls, inner coat percentage was separated and calculated. Wool paralled by Fibroliner and fiber length measured with Almeter instrument. Wool diameter determined by Microprojection microscop [7]. Data analyzed by SAS software using GLM and Duncan's multiple range tests was used for comparison of mean wool characteristics.

$$
\gamma_{j k m}=\mu+\alpha_{i}+\beta_{j}+\delta_{k}+\varepsilon_{i j k m}
$$

where:

$\gamma_{j k m}$ is an individual record,

$\mu$ is the population mean,

$\alpha_{i}$ is the effect of $i^{\text {th }}$ age group,

$\beta_{j}$ is the effect of $j^{\text {th }}$ sex,

$\delta_{k}$ is the effect of $k^{\text {th }}$ generation and

$\varepsilon_{i j k m}$ is the residual effects.

\section{RESULTS}

Mean of fiber quality and quantity characteristics are presented in Table 1.

\subsection{Staple and Fiber Barbe Length}

Sex and generation had significant influence $(\mathrm{p}<0.05)$ on staple and fiber barbe length. This is in conformity with finding of others that indicated the male and backcross crossbred had longer fiber and staple length. There was no difference among ages groups. In $\mathrm{F}_{2}$ backcrosses there were significant differences in the staple and fiber length and a slight increase the greasy fleece weight. However this fiber length is shorter than the fiber length of for wool of native sheep but it is compatible with Cashmere goat fiber [8].

\subsection{Fine Fiber Percentage}

Fine fiber percentage affected in female only $(p<$ $0.05)$. Males had more fine fiber percentage than female crosses, but no differences among generation or age groups. Fine fiber percentage of Iran cashmere fleece is $1 / 3$ of total fleece weight (13), but in crossbred sheep is $1 / 2$ of total fleece weight.

\subsection{Average Fiber Diameter}

As it is shown in Table 1, mean fiber diameter of flock is low, especially in male and younger animals, it is very important in selection and animal breeding. Sex, age and generation contributed to variation in mean fiber diameter, but only sex had significant influence $(p<0.05)$ on mean fiber diameter. There was a marked reduction in average fiber diameter in crossbred sheep over the parents. $F_{1}$ lambs had the finest fiber and more superior to $\mathrm{F}_{2}$ backcrosses. In $\mathrm{F}_{1}$ there was further movement in the quality character. The results showed an advantage for first cross but diminished in back crosses. Ghanem [9] observed the same results. Average fiber diameter in this research is finer than Iran cashmere fiber $(17-20 \mu \mathrm{m})$.

\subsection{Fleece Weight}

Sex and age significantly contributed to variation in fleece weight, however average fleece weight in $F_{2}$ was heavier than $\mathrm{F}_{1}$ but it was not significant. Age at shearing time influenced significantly the greasy fleece weight. Because of large body size, males produced heavier fleece weight. Mittal and Pandey [10] observed the effect of age on wool yield. Half-bred were superior to wild in greasy wool production. Half-bred were superior to pure bred in most of wool traits, but in contrast to (FNS) had a negative effect on greasy fleece weight. In general $F_{1}$ resulted in a slight decline in greasy wool production.

\subsection{Clean Wool Yield}

The wool yield did not affected by sex, age and generation. The yield in coarse wool is more than medium and fine wool, but mean yield percentage in crossbred was higher than other Iranian sheep breeds.

Table 1. Crossbred wool characteristics of Farahani native sheep X Baghdadi wild ram separated by sex, generation and age.

\begin{tabular}{|c|c|c|c|c|c|c|c|c|c|}
\hline \multicolumn{2}{|c|}{ Variables } & \multirow{2}{*}{$\begin{array}{c}\mathbf{n} \\
12\end{array}$} & \multirow{2}{*}{$\begin{array}{c}\begin{array}{c}\text { Fleece weight } \\
\text { (g) }\end{array} \\
506.56^{\mathrm{a}}\end{array}$} & \multirow{2}{*}{$\begin{array}{c}\begin{array}{c}\text { Wool diameter } \\
(\boldsymbol{\mu m})\end{array} \\
12.78^{\mathrm{a}}\end{array}$} & \multirow{2}{*}{$\begin{array}{c}\begin{array}{c}\text { CV of diameter } \\
\text { (\%) }\end{array} \\
19.25^{\mathrm{a}}\end{array}$} & \multirow{2}{*}{$\begin{array}{c}\begin{array}{c}\text { Fine fiber } \\
\text { (\%) }\end{array} \\
42.50^{\mathrm{a}}\end{array}$} & \multirow{2}{*}{$\begin{array}{c}\begin{array}{c}\text { Staple length } \\
\text { (mm) }\end{array} \\
41.53^{\mathrm{a}}\end{array}$} & \multirow{2}{*}{$\begin{array}{c}\begin{array}{c}\text { Barbe length } \\
\text { (mm) }\end{array} \\
27.96^{\mathrm{a}}\end{array}$} & \multirow{2}{*}{$\begin{array}{c}\text { Yield (\%) } \\
64.87^{\mathrm{a}}\end{array}$} \\
\hline & Male & & & & & & & & \\
\hline sex & Female & 6 & $259.00^{\mathrm{b}}$ & $15.33^{\mathrm{b}}$ & $25.10^{\mathrm{b}}$ & $48.67^{\mathrm{a}}$ & $35.81^{\mathrm{a}}$ & $34.98^{\mathrm{b}}$ & $65.99^{\mathrm{a}}$ \\
\hline \multirow{2}{*}{ Generation } & $\mathrm{F}_{1}$ & 11 & $435.08^{\mathrm{a}}$ & $11.84^{\mathrm{a}}$ & $22.04^{\mathrm{a}}$ & $37.75^{\mathrm{a}}$ & $33.34^{\mathrm{a}}$ & $23.26^{\mathrm{a}}$ & $62.34^{\mathrm{a}}$ \\
\hline & 1 & 4 & $248.25^{\mathrm{a}}$ & $12.55^{\mathrm{a}}$ & $25.56^{\mathrm{a}}$ & $37.50^{\mathrm{a}}$ & $36.65^{\mathrm{a}}$ & $23.80^{\mathrm{a}}$ & $70.64^{\mathrm{a}}$ \\
\hline \multirow[t]{2}{*}{ Age (year) } & 2 & 9 & $458.38^{b}$ & $14.47^{\mathrm{b}}$ & $17.60^{\mathrm{a}}$ & $44.44^{\mathrm{a}}$ & $41.63^{\mathrm{a}}$ & $34.60^{\mathrm{a}}$ & $63.19^{\mathrm{a}}$ \\
\hline & 3 & 7 & 637.75 & $13.11^{\mathrm{b}}$ & $22.77^{\mathrm{a}}$ & $48.14^{\mathrm{a}}$ & $39.24^{\mathrm{a}}$ & $26.01^{\mathrm{a}}$ & $64.51^{\mathrm{a}}$ \\
\hline
\end{tabular}

*Mean within a column are significantly different $(\mathrm{p}<0.05)$. 
It can be concluded that crossbreeding between Farahani and wild ram resulted in improving in the mean wool fiber diameter, fiber length uniformity in crosses. Increase inheritance beyond $50 \%$ had a positive effect on the mean wool fiber diameter, but negative influence on the staple length, fiber length and on greasy fleece weight.

\section{CONCLUSION}

This research described the results of crossbreeding experiment for improving the wool production and quality involving Baghdadi wild ram with kempy coat and Farahani native sheep breed with carpet wool type. At the end of winter like wild sheep, seasonal fiber shedding in $F_{1}$ is observed, but it is seldom occurred in $F_{2}$. Crossbred wool diameter indicated that there is a good potential for super fine wool production. It is mentioned that the fleece is pie bald but the colored wool are coarse fiber. It would be feasible to utilize the crossbred for evolving new fine fiber through selection. New fiber is finer than super fine wool Merino and cashmere fiber that can be used pure or blend with the other fibers for different textile products.

\section{ACKNOWLEDGEMENTS}

We thank the staff of Animal Science Research Institute (ASRI) and colleague in department of animal science research in Markazi province, for providing necessary facilities for carrying out this work.

\section{REFERENCES}

[1] Taherpour-dari, N. (1988) A review on the most important studies of wool characteristics of Iranian native sheep. Animal Science Research Institute of Iran, Karaj.

[2] Satari, M. (1975) Sheep breeding in Iran. Breeds, nutrition, raising. Tehran University, Tehran.

[3] Sohraby, S. (1937) Les races de moutons et la laine de I, Iran. L. Rodstein, Paris.

[4] Nadler, C.F., Lay, D.M. and Hassinger, J.D. (1971) Cytogenetic analyses of wild sheep population in northern Iran. Cytogenetics, 10, 137-152. doi:10.1159/000130135

[5] Aliev G.A. and Racgkorskii M.L. (1986) The genetics of wool colour in wiled sheep. Vklad genet $\mathrm{v}$ uskorenie, Dushanbe.

[6] Pakov, S.L. (1976) Variability of undercoat production. Length and fines in wiled rams and indigenous breed of sheep. Trudy-Vesesoyuznogo-Sel, Skokhozyaistvvenho-Intituta-Zaochnogo-Obrazovnya, 114, 96-102.

[7] American Society of Testing Materials. (1987) Test method for wool and other animal fibers micro projection D21300. Annual book of ASTM Standards, ASTM, West Conshohocken.

[8] Salehi, M., Taherpour-dari, N. and Beheshti, A.M. (2000) Effect of some environmental factors (sex and age) and two management system (station and migrate) in Raeini goats. Pajouhesh-va-Sazandegi, 2, 4-19.

[9] Ganem, E.S.E. (1976) Wool studies of crossbred Merino Baraki sheep living under desert condition. Bulletin de I'Institut du Desert d'Egypt, T.xv No 53.

[10] Mittal, G.P. and Pandey, M.D. (1976) Effect of age and season on wool yield in Bikaneri ewes. Indian Journal of Animal Sciences, 45, 161-162. 